\title{
Morphological Study on Snow Crystals Abnormally Extended to the B-Axis
}

\author{
By Nobuyuki Yamami and Choji Magono \\ Department of Geophysics, Hokkaido University, Sapporo \\ (Manuscript received 6 April 1977, in revised form 26 December 1978)
}

\begin{abstract}
Snow crystals extended in the direction of the $b$-axis were observed in a temperature range from $-8^{\circ} \mathrm{C}$ to $-10^{\circ} \mathrm{C}$ at the summit of Mt. Teine. They had almost the skeleton structure and possessed double plates. Observing this type of snow crystals in different stages, it was considered that when a prism face develops abnormally in the direction of the $b$-axis, neighbouring two frames curve and approach to each other, and then are combined to a new frame extending in the direction.

The occurrence frequency of this type of crystals was about $2 \%$ in all snow crystals observed throughout 10 hours. This type of snow crystals was morphologically the same as Schaefer's flare crystals and Yamashita's trigonal dendrites except for a strange behaviour of frames.

It is considered that the abnormal growth towards the $b$-axis occurs when a prism face develops at a rate of more than twice of those of neighbouring prism faces. Snow crystals with the repeated growth of the $b$-axis were also observed. It is considered that the repeated growth of the $b$-axis was due to the bunching of growth layers.
\end{abstract}

\section{Introduction}

Branches of snow crystals extend in general in the direction of the $a$-axis. However, when one of the authors made an observation of snow crystals at the summit of Mt. Teine, a considerable number of abnormal snow crystals were found. That is, the snow crystals appeared to develop abnormally in the direction of the $b$ axis $\langle 10 \overline{1} 0\rangle$ : intermediate direction between two $a$-axes. The frames of the branches in the direction exhibited a strange behaviour. This type of snow crystals are not seen in the general classification of Nakaya (1954) and the meteorological classification by Magono and Lee (1966). They appear to be correlated with Schaefer's flare crystals (1968) and Yamashita's trigonal dendrites (1973). This paper will describe morphologically the snow crystals abnormally extended to the $b$-axis and the result of considerations regarding the formation mechanism.

\section{Observation}

\subsection{Method}

The observation was carried out at the top of
Mt. Teine (1,024 $\mathrm{m}$ above sea level), Hokkaido, Japan in the period from Jan. 15 to 30, 1974. Snow crystals were sampled on slide glasses coated with silicon oil and were examined under a polarization microscope. Simultaneously, snow crystals were sampled by the replica solution method (Formvar solution in $0.6 \%$ in $\mathrm{C}_{2} \mathrm{H}_{2} \mathrm{Cl}_{2}$ ) at time intervals of 15 to 30 minutes. The number concentration of snow crystals was measured by sweeping a volume by a slide glass $(6 \mathrm{~cm} \times$ $9 \mathrm{~cm})$.

\subsection{Meteorological situation}

On 26 January 1974, a number of snow crystals with branches which extended to the $b$ axis and scalene hexagonal crystals were observed. The observation site was covered by supercooled clouds of temperatures from $-8^{\circ} \mathrm{C}$ to $-10^{\circ} \mathrm{C}$. On the day, the Hokkaido Island was under the influence of a cyclone and Mt. Teine was covered with clouds throughout that day. Fig. 1 shows the vertical distribution of air temperature and humidity which were measured in the morning by the Sapporo Meteorological Observatory at a $12 \mathrm{~km}$ east from the 
mountain.

\subsection{Structure of snow crystals with branches} extended to the b-axis

The explanation of naming of snow crystals in this paper is given in Fig. 2. In snow crystals of skeleton type, six lines run from the center of crystals to the corners. They are called "frames". If a corner of a double plate crystal is abnormally extended in the direction of the $b$ axis, it is called the " $b$-branch". The frame in the direction of the $b$-axis called the " $b$-frame".

Examples of snow crystals with branches extended in the direction of the $b$-axis are shown

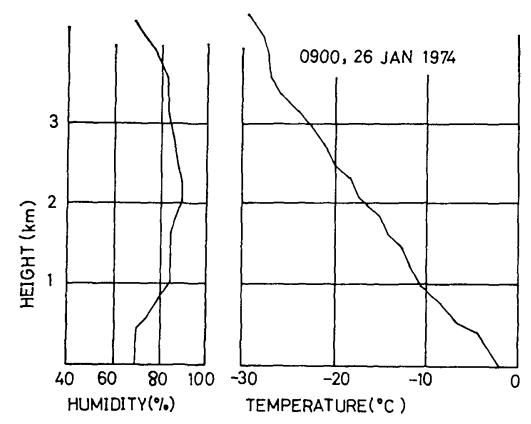

Fig. 1 Vertical distribution of humidity and temperature. in Figs. 3 and 4. It may be seen in Fig. 3(a) that two skeleton frames curved and are approaching each other. In the case of Fig. 3(b), two skeleton frames are joined and the prism face disappears. Then, a pointed branch is formed in the direction of the $b$-axis. This is the $b$ branch. The corner angle of the $b$-branch is about $60^{\circ}$ and the crystal form becomes a pentagon. The crystal in Fig. 3(a) may be in the early stage of the $b$-branch.

Fig. 3(c) shows a snow crystal with a well developed $b$-branch. It may be seen that two
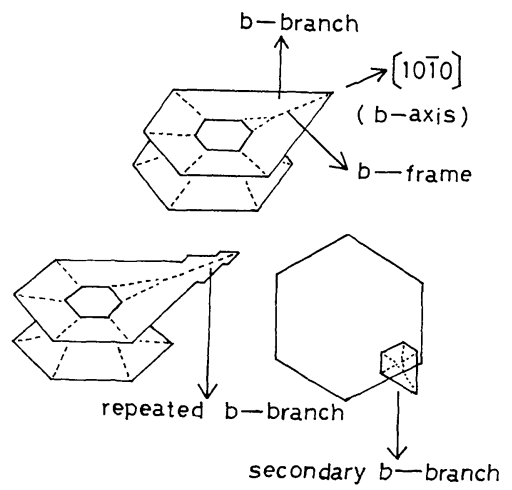

Fig. 2 Names of $b$-branch snow crystals.

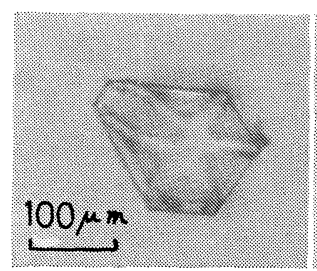

(a)

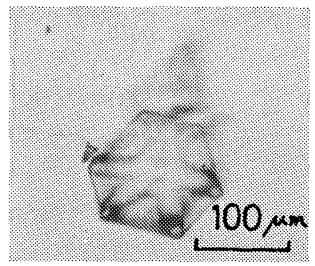

(d)

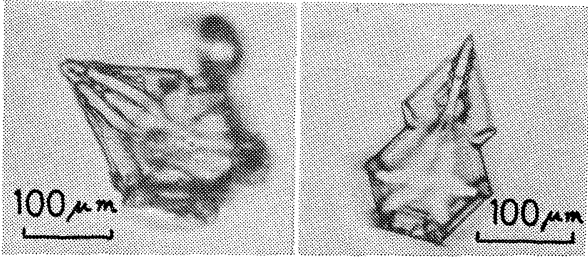

(b)

(c)

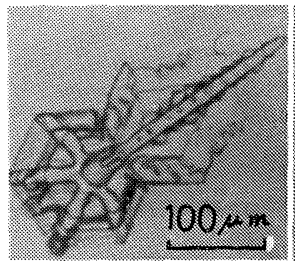

(e)

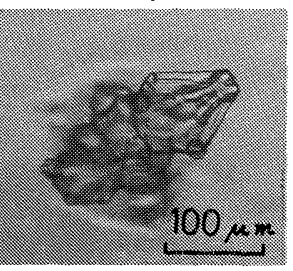

(f)

Fig. $3 \quad B$-branch snow crystals.

(a) Two skeleton frames are curved, approaching each other.

(b) Two skeleton frames are joined.

(c) Two frames are joined, then a $b$-frame is formed. Focussing at upper plane.

(d) Focussing at lower plane of crystal (c).

(e) A $b$-frame is seen starting from the center of a crystal.

(f) A joined frame is seen separating again. 


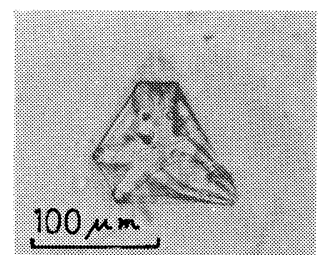

(a)

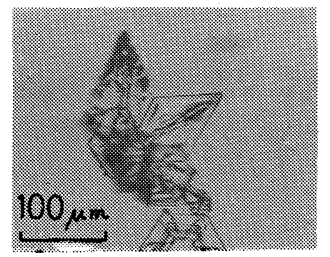

(d)

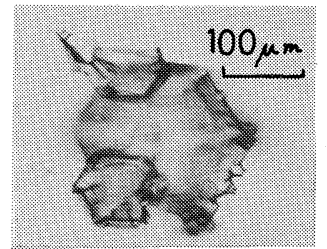

(g)

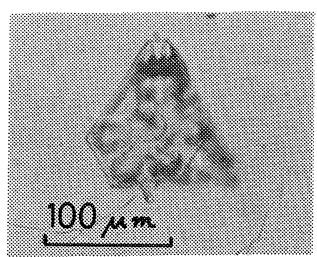

(b)

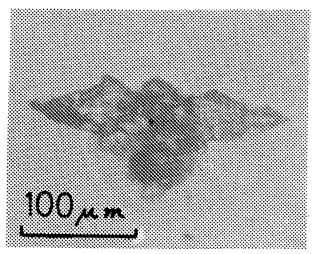

(e)

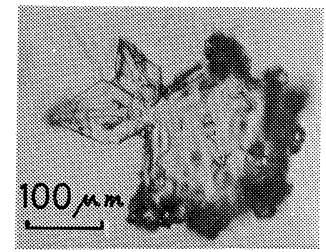

(h)

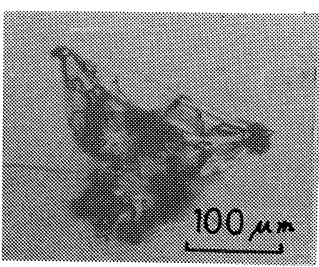

(c)

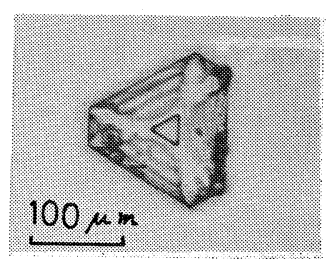

(f)

Fig. 4 Snow crystals with plural $b$-branches.

(a) Upper plane of two $b$-branches crossing at $120^{\circ}$.

(b) Another $b$-branch at lower plane of crystal (a).

(c) Two $b$-branches crossing at $120^{\circ}$ on the same plane.

(d) Two $b$-branches crossing at $60^{\circ}$ at different planes.

(e) Two $b$-branches crossing at $180^{\circ}$ on the same plane.

(f) Trigonal snow crystal with divided frames in the early stage.

(g) Secondary $b$-branch which grew from a frozen droplet.

(h) Two secondary $b$-branches crossing at $60^{\circ}$ which develop from a corner of a mother crystal.

joined skeleton frame developed again towards the $b$-axis. This is an example of the $b$-frame. It may be also seen that the formation of the $b$ branch was repeated at twice. Such branches are called "repeated $b$-branches" in this paper.

When the focussing of microscope was at the lower plane of Fig. 3(c), the structure was a hexagonal plate as shown in Fig. 3(d). This implies that the snow crystal consists of double plates. The upper plate has a $b$-branch, but the lower plate is a hexagonal plate. Almost $b$ branch snow crystals observed in this work consisted of double plates.

In the case of Fig. 3(e), the $b$-frame is originated from the center of the crystal and the $b$ branch develops repeatedly to "flare crystals" which were named by Schaefer and Cheng (1968). The crystal was a single crystal according to the observation under a polarization microscope. In some cases, it was observed that joined frames were separated again and a prism face began to form as shown in Fig. 3(f).

Not only snow crystals with one $b$-branch, but also with two or three $b$-branches were observed as illustrated in Fig. 4. The snow crystal in Fig. 4 (a) and (b) has two $b$-branches crossing at $120^{\circ}$ at different plates. One develops from the upper plate (a), another from the lower plate (b). In the case of Fig. 4(c), two b-branches extended from the same plate crossing at $120^{\circ}$. In the case of Fig. 4(d), two $b$-branches extend from different plates crossing at $60^{\circ}$. In the case of Fig. 4(e), two $b$-branches extend to both sides. Fig. 4(f) shows an example of snow crystal in an early stage when three $b$-frames begin to separate. The development stage of this type may be of 
trigonal dendrites which were named by Yama- "secondary $b$-branches" in this paper.

shita (1973). In some cases, it was observed that The $b$-branch snow crystals observed, were $b$-branches appeared to extend from frozen cloud classified into four groups according to the numdroplets on a snow crystal, as shown in Fig. 4(g) ber of $b$-branches and their occurrence frequency and (h). This type of $b$-branch will be called are listed in Fig. 5. It may be seen that snow

\begin{tabular}{|c|c|c|c|}
\hline No. of $b$-branches & Types of $b$-branches & Symbol & $\begin{array}{l}\text { No. of snow } \\
\text { crystals }\end{array}$ \\
\hline \multirow{5}{*}{ One $b$-branch } & Two curved frames & & 16 \\
\hline & Joined $b$-frame & & 31 \\
\hline & $\begin{array}{l}\text { Joined } b \text {-frame is seen } \\
\text { separating again }\end{array}$ & & 12 \\
\hline & $\begin{array}{l}B \text {-frame starting from } \\
\text { the center }\end{array}$ & & 61 \\
\hline & Separating $b$-frame & & 15 \\
\hline \multirow{4}{*}{ Two $b$-branches } & $\begin{array}{l}\text { Crossing at } 60^{\circ} \text { at } \\
\text { different plane }\end{array}$ & & 2 \\
\hline & $\begin{array}{l}\text { Crossing at } 120^{\circ} \text { at } \\
\text { same plane }\end{array}$ & & 1 \\
\hline & $\begin{array}{l}\text { Crossing at } 120^{\circ} \text { at } \\
\text { different plane }\end{array}$ & & 5 \\
\hline & $\begin{array}{l}\text { Crossing at } 180^{\circ} \text { at } \\
\text { same plane }\end{array}$ & & 1 \\
\hline Three $b$-branches & $\begin{array}{l}\text { Crossing at } 120^{\circ} \text { at } \\
\text { same plane }\end{array}$ & & 1 \\
\hline Secondary $b$-branches & & & 33 \\
\hline
\end{tabular}

Fig. 5 Observed number of various types of $b$-branch snow crystals. The solid line represents the same plane and the broken line represents different planes. 
crystal with single $b$-branch is more frequent than with plural $b$-branches.

\subsection{Occurrence frequency of b-branch snow crystals}

On 26 Jan., snow crystals of $b$-branch type were frequently observed together with snow crystals of hollow prisms and thick plates. The change in the concentration of $b$-branch snow crystals and the relative frequency to the other type is shown in Fig. 6. The temperature range at the observation site is $-8^{\circ} \mathrm{C}$ to $-10^{\circ} \mathrm{C}$. The relative frequency of $b$-branch snow crystals was on the average about $2 \%$. It is noted that $b$ branch snow crystals were observed steadily throughout 10 hours in natural clouds. The size of $b$-branch snow crystals was 50 to $300 \mu \mathrm{m}$ in diameter. Therefore, it is considered that these snow crystals in the early stage were formed near the observation site. Considering the other type of snow crystals which were simultaneously observed (Magono and Lee, 1966) and the air temperature at the observation altitude, the temperature condition for the formation of $b$-branch snow crystals may be about $-10^{\circ} \mathrm{C}$.

\subsection{Stepped structure of $b$-frames}

A $b$-frame showed a stepped (or terraced) structure under high magnification photographs as illustrated in Fig. 7(a). It may be seen that the stepped structure is the assembly of overlapped micro hexagonal plates on the line of the $b$-frame and that the direction of the $b$-frame is perpendicular to the prism face of these hexagonal plates as schematically shown in Fig. 7(b). It is therefore suggested that the face of top of the $b$-branch is one of the prism faces of a hexagonal plate, although $b$-branches apparently have an edges with an angle of about $60^{\circ}$. In other

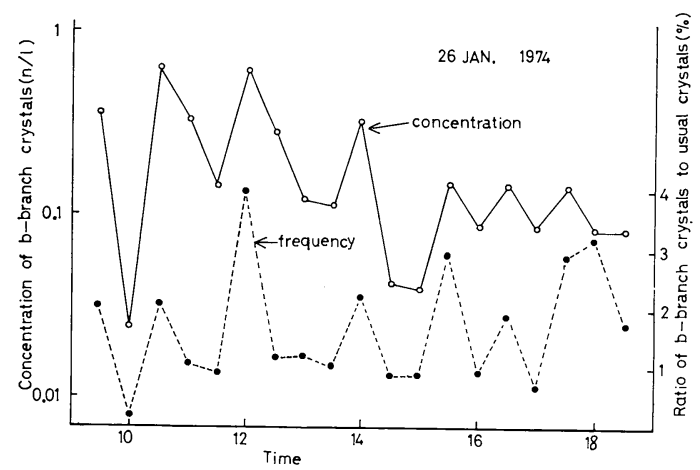

Fig. 6 Occurrence frequency and concentration of $b$-branch snow crystals.

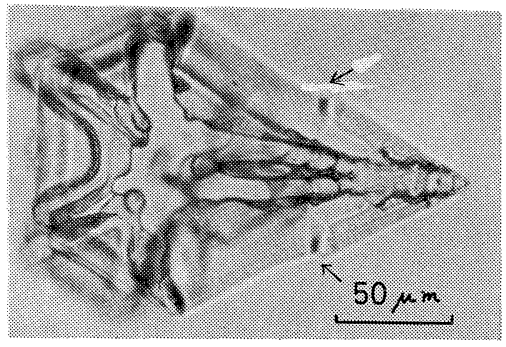

(a)

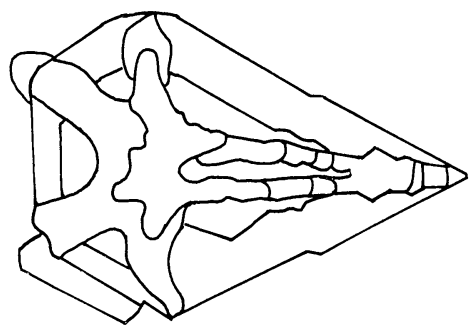

(b)

Fig. 7 Stepped structure of the $b$-frame.

normal corners, however the corner of micro plates coincide with the original plate. These stepped structure of frames are considered to be scalelike skeletons of ridges by Nakaya (1954).

\subsection{Growth rate of prism faces of b-branches}

As described in (2.5), the top of $b$-branch is constructed of one of micro prism faces, even if it appears to be pointed. If the growth rates of six prism faces of a hexagonal plate are equal, the shape of crystal will be regular hexagon and six skeleton frames symmetrically run to the $a$ axis in the straight line. Therefore, the curving of skeleton frames and the formation of $b$ frames must be due to abnormal growth rates of some of six prism faces. It was observed in the microphotograph of high magnification that the $b$-branch snow crystal in a early stage has parallel line structures as illustrated in Fig. 3(a) which is represented schematically in Fig. 8. The width of parallel structures is considered to indicate the growth history and the growth rate of prism faces of the crystal. It may be seen that the growth rate of the abnormal prism face is about four times greater than normal prism faces.

If one of prism faces grows much greater than other prism faces, its area becomes relatively narrower as the face grows. If the growth rate of an abnormal face is twice that of other faces, 


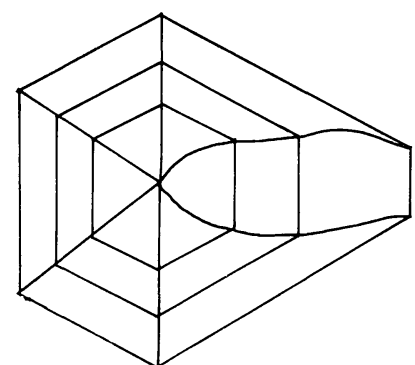

Fig. 8 Growth rate of the $b$-branch.

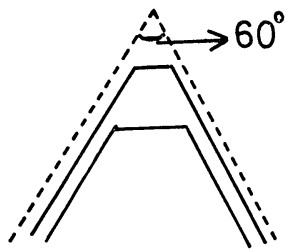

Fig. 9 The face of abnormally growing prism face becomes narrower.

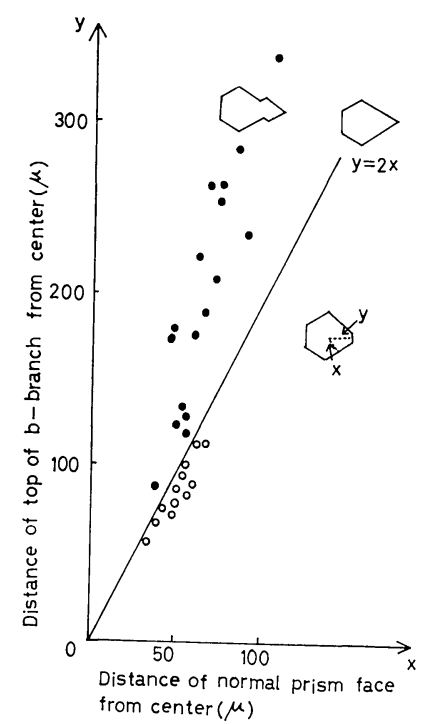

Fig. 10 Growth mode of $b$-branch snow crystals.

the abnormal face tends to have an apparently sharp edge of $60^{\circ}$ as shown in Fig. 9 and if the rate is greater than twofold, the formation of $b$ branch is repeated. It is considered that the repeated growth of $b$-branches are produced by the bunching because the growth rate at the top of $b$-branches is very high. Arrows in Fig. 7(a) shows the early stage of the bunching. In such a case, the angle of edge was a little smaller than $60^{\circ}$.
In Fig. 10, the distance of the abnormal prism face from the center of pentagonal crystals is plotted against that of normal prism face. Repeated $b$-branches are shown by black circles and the other pentagonal crystals and scalene crystals are shown by white circles. If a $b$ branch crystal is originally of pentagon shape, the relation between the distances of abnormal and normal faces will be described by a straight line with an inclination of $\tan ^{-1} 2$, to the horizontal axis. It may be seen in tne figure that white circles roughly coincides with the straight line in the early stage, but as the distance excesses are $50 \mu \mathrm{m}$ in the $x$-axis, the distance of abnormal prism face is considerably greater than described by the line. This implies that when the growth rate of abnormal prism face is greater than the twofold of those of other normal faces, the $b$-branch takes a repeated form.

\section{Discussion}

Yamashita (1973) has postulated that the hexagonal crystal does not become the pentagonal crystal, but the latter originates from the small pentagonal crystal. However, the results of the present observation shows many indications for the change from the hexagon to the pentagon in our $b$-branch snow crystals as shown in Fig. 3(a) and 3(b). On the other hand, in some cases, there is an indication that pentagonal crystals tend to become regular hexagonal ones as shown in Fig. 3(f).

Now, let us consider the growth condition of $b$-branch snow crystals. As already described, $b$-branch snow crystals were observed in a temperature range from $-8^{\circ} \mathrm{C}$ to $-10^{\circ} \mathrm{C}$ in supercooled clouds. The humidity condition may be the same as the skeleton growth, because the $b$ branch snow crystals were observed simultaneously with usual skeleton form crystals. But, Schaefer and Cheng (1968) obtained $b$-branch snow crystals in a temperature range of $-20^{\circ} \mathrm{C}$ by $\mathrm{AgI}$ pyro-technique. Also, Yamashita (1973) obtained trigonal dendrites in a temperature range of $-26.8^{\circ} \mathrm{C}$ by seeding with a very cold body. Recently, Kikuchi (1974) reported $b$-branch snow crystals at colder temperature range than $-20^{\circ} \mathrm{C}$ at Antarctica. Accordingly, it is considered that there is a warm range and a cold range for the temperature condition of $b$-branch snow crystals. Incidentally, according to Yamashita's experiment, regular hexagonal crystals predominate at around $-15^{\circ} \mathrm{C}$.

A few snow crystals of $b$-branch type are seen 
in the snow crystal photographs of Bentley and Humphreys (1931) (p. 201) and by Klinov (1960) (p. 58). But, the growth condition of the crystal are not clear.

As described above, $b$-branch snow crystals were observed at various locations of the world, although the occurrence frequency were very low. But, the average occurrence frequency was about $2 \%$ throughout 10 hours in the present observation at $\mathrm{Mt}$. Teine.

Three possible mechanisms may be considered for the abnormal growth to the $b$-axis. The first is the heterogeneity of water vapor diffusion field around a snow crystal. The second is the effect of impurities. Flare crystals obtained by AgI pyrotechnique and trigonal dendrites by seeding with a very cold body suggest the importance of nucleation process. The last is the presence of dislocations. If the density of dislocations on some prism faces are larger than other prism faces, the prism faces will grow in the direction of the $b$-axis.

\section{Conclusion}

Various kinds of $b$-branch snow crystals were observed at a percentage of $2 \%$ throughout 10 hours. Analysing the snow crystals of $b$-branch type in different stage, the developing process of $b$-branches were followed, and it was concluded that the $b$-branches were formed by abnormal growth of several prism faces. And the formation of repeated $b$-branches was due to the bunching of growth layers. The flare crystals and trigonal dendrites are morphologically in- cluded into the class of the $b$-branch snow crystals. It was found that there are two temperature regions for the $b$-branch snow crystals, one is around $-10^{\circ} \mathrm{C}$, and the other is a very cold temperature region. The formation condition other than temperature was not found. Further studies are hoped for the formation condition of $b$-branch snow crystals.

\section{Acknowledgements}

The authors wish to express their thanks to the Cloud Physics Group of Hokkaido University for their valuable discussions and encouragements.

\section{References}

Bentley, W. A. and W. J. Humphreys, 1931: Snow Crystals. MacGraw-Hill, London and New York. 226 pp.

Kikuchi, K., 1974: Natural snow crystals-on peculiar snow crystals and polycrystals. Kishō Kenkyu Note. Met. Soc. Japan, 123, 1-45.

Klinov, F. Ya., 1960: Voda $v$ atmosfere pri nizki temperatura. Akad. Nauk SSSR. $170 \mathrm{pp}$.

Magono, C. and C. W. Lee, 1966: Meteorological classification of natural snow crystals. J. Fac. Sci., Hokkaido Univ., Ser. VII, 2, 321-335.

Nakaya, U., 1954: Snow Crystals. Harvard Univ. Press, $510 \mathrm{pp}$.

Schaefer, V. J. and R. J. Cheng, 1968: The effect of the nucleus on ice crystal structure. Proceedings of the International Conference on Cloud Physics, Toronto, 255-259.

Yamashita, A., 1973: On the trigonal growth of ice crystals. J. Met. Soc. Japan, 51, 307-317.

\title{
B 軸方向に異常に成長した雪の結晶に関する形態学的研究
}

\author{
山 見 信 之・孫 野 長 治 \\ 北海道大学理学部地球物理学教室
}

$\mathrm{B}$ 軸方向に成長した雪が手稲山頂で $-8^{\circ} \mathrm{C}$ から $-10^{\circ} \mathrm{C}$ の温度領域で観測された。それらは, ほとんぞ影晶構造 をして扣り double plate を持っていた。いろいろな成長段階でこの型の結晶を観湘する事によって次の事が考察さ れた。あるプリズム面が b 軸方向に異常に成長する時となりあう，二つの frame は曲がり，お互いに近づきとし て，ひとつの新しい frame に結合してその方向に伸びる。

このタイプの結晶の出現頻度は，10時間の間，観測されたすべての雪の結晶のうち約 $2 \%$ であった。また， Schaefer 等の flare crystals, Yamashita の trigonal dendrites と, frame の奇妙なふるまいを除いて, 形態学 的に同じである。

B 軸方向の異常成長は，あるプリズム面がとなりあう二つのプリズム面より 2 倍以上の成長速度を持つ時に生じる と考光られる。またその方向へのくり返し成長は，bunching によるものと考光られる。 